\title{
Changes in physical properties of extruded sour cassava starch and quinoa flour blend snacks
}

\author{
Mudanças nas propriedades físicas de snacks extrusados de misturas de polvilho azedo e farinha de quinoa
}

\author{
Lívia Giolo TAVERNA ${ }^{1}$, Magali LEONEL ${ }^{1 \star}$, Martha Maria MISCHAN ${ }^{2}$
}

\begin{abstract}
Given the broad acceptance of sour cassava starch biscuits in Brazil and the nutritional quality of quinoa flour, this study aimed to evaluate the effect of extrusion temperature, screw speed, moisture, and amount of quinoa flour on the physical properties of puffed snacks. Extrusion process was carried out using a single-screw extruder in a factorial central composite design with four factors. Effects of moisture and amount of quinoa flour on the expansion index and specific volume of snacks were observed. There was a pronounced increase in water solubility index of blends with the extrusion process with significant effects of all process parameters on the WSI. Higher water absorption index (WAI) was observed under high temperature, low moisture, and lower quinoa flour amount. Temperature and amount of quinoa flour influenced the color of the snacks. A positive quadratic effect of quinoa flour on hardness of products was observed. Blends of sour cassava starch and quinoa flour have good potential for use as raw material in production of extruded snacks with good physical properties.
\end{abstract}

Keywords: extrusion; Manihot esculenta; pseudo-cereal.

\section{Resumo}

Dada a ampla aceitação do biscoito de polvilho azedo no Brasil e a qualidade nutricional da farinha de quinoa, este trabalho objetivou avaliar o efeito da temperatura de extrusão, rotação da rosca, umidade e porcentagem de farinha de quinoa sobre as propriedades físicas de snacks expandidos. O processo foi realizado em extrusor monorrosca, seguindo o delineamento central composto rotacional para quatro fatores. Foi observado o efeito da umidade e da porcentagem de farinha de quinoa sobre o índice de expansão e volume específico. Houve um aumento pronunciado na solubilidade das misturas com o processo de extrusão, com efeitos significativos de todos os parâmetros de processo no ISA. Maior índice de absorção de água (IAA) foi observado em alta temperatura, baixa umidade e menor porcentagem de farinha de quinoa. Temperatura e porcentagem de farinha de quinoa tiveram efeito sobre a cor dos produtos. Foi observado o efeito quadrático positivo de farinha de quinoa na mistura sobre a dureza dos produtos. Misturas de polvilho azedo e farinha de quinoa têm um bom potencial para utilização como matéria-prima na produção de snacks extrusados com boas propriedades físicas.

Palavras-chave: extrusão; Manihot esculenta; pseudocereal.

\section{Introduction}

Extrusion has gained attention and emphasis in the food industry since it is an important technique which, besides increasing the variety of processed food, presents more advantages when compared with other traditional systems of food processing.

The rapid acceptance of food extrusion as an important food processing operation results from the many advantages of the use of extrusion. First, extruders achieve high productivity in a single processing step by cooling and forming the product, thus enhancing the cost effectiveness of the process. The ability of an extruder to handle a wide variety of raw ingredients and processing conditions assures its versatility and consequently broadens its applicability to a myriad of food products (HARPER, 1981; GUY, 2001).

Consumer acceptance of extruded foods is mainly due to the convenience, value, attractive appearance, and texture found to be particular for these foods, especially when it concerns snack products (ANTON et al., 2008).

Brazil is the third largest producer of cassava $(233,795,973$ tons), accounting for $13.86 \%$ of the worldwide production. Cassava is grown in all regions of Brazil, taking outstanding importance in food and feed, and it is used as a raw material in numerous industrial products (LEONEL; FREITAS; MISCHAN, 2009).

The sour cassava starch is a natural latic-fermented and sun-dried modified starch. This modified starch is widely used in food products due to its natural expansion property (BERTOLINI et al., 2001). It is found in all South American countries, except for Ecuador.

Today's health conscious consumers have shown a preference towards value added products, and in general, more

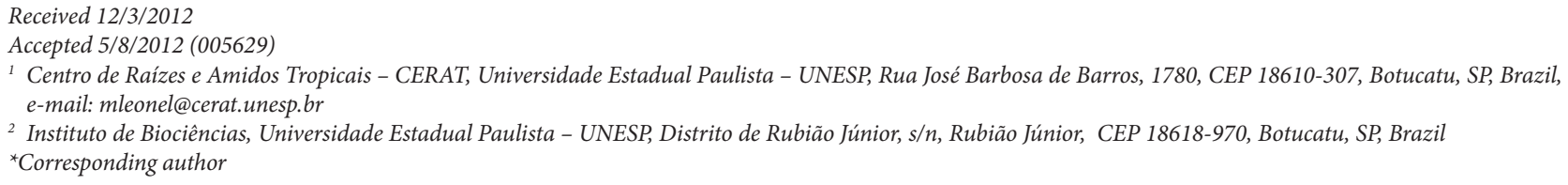


nutritious food items (BRADY et al., 2007). The opportunity to supplement common biscuits of sour cassava starch with a cereal of higher nutritional value is inherently beneficial to public interests.

Cereals and to a less degree pseudo-cereals meet the major worldwide protein intake requirements. However, there has been a growing interest by the food industry for pseudo-cereals no allergens such as amaranth and quinoa.

Quinoa (Chenopodium quinoa Willd.) is an annual crop of the family Chenopodiaceae, which has been cultivated in different regions in South America. Quinoa seed was introduced in Brazil in the 1990s. During the selection process, several genotypes were obtained, and the BRS Piabiru became the first recommendation for cultivation in the country, with average yield of approximately $2.8 \mathrm{t} \mathrm{ha}^{-1}$. The cultivated area, however small, has the potential to grow to meet demand, now stimulated by the imported product. Attractive prices do increase the interest of producers, researchers, and food industry (BORGES et al., 2010). Considered a pseudo-cereal or pseudo-grain, quinoa has been recognized as a complete food due to its protein quality. It has remarkable nutritional properties; not only from its protein content (15\%), but also from its great amino acid balance. It is an important source of minerals and vitamins, and it has also been found to contain compounds like polyphenols, phytosterols, and flavonoids with possible nutraceutical benefits (JAMES, 2009). The quinoa flour contains about 135 g.kg ${ }^{-1}$ protein, 63 g. $\mathrm{kg}^{-1}$ lipids, 95 g. $\mathrm{kg}^{-1}$ crude fiber, $12 \mathrm{~g} \cdot \mathrm{kg}^{-1}$ total ash, and $583 \mathrm{~g} . \mathrm{kg}^{-1}$ carbohydrate (based on 110 g.kg $^{-1}$ moisture) (OGUNGBENLE, 2003).

In general, extrusion of starchy foods results in gelatinization of starch, denaturation of protein, and formation of complexes between starch and lipids and between proteins and lipids (GUY, 2001).

The complexes between starches and lipids are due to the ability of the amylose fraction of starches to bind lipids such as fatty acids. The decrease in expansion and the increase in bulk density of starch can also be compared to the swelling of native starch upon gelatinization. Swelling is generally considered a property of amylopectin. Amylose is considered a diluent. The amylase and native lipids present in cereal starches may inhibit swelling under conditions when amylose-lipid complexes are likely to be formed. Lipid complexation with starch is a very important reaction in extrusion cooking that affects structure formation and texture of the extruded products (BHATNAGAR; HANA, 1994; DE PILLI et al., 2011).

During extrusion, due to the effect of high temperature and mechanical forces, proteins lose their globular structure. There occurs cleavage of bonds responsible for the $2^{\text {nd }}$ and $3^{\text {rd }}$ order structure of proteins, due to which polypeptide chains become straightened and extended and unfolded protein structures subjected to the effect of mechanical forces form layered structures (CAMIRE; CAMIRE; KRUMHAR, 1990). Proteins can form non-covalent disulphide bonds, block polar groups, form complexes with oxidized lipids, and create complexes of Maillard reaction products. On the other hand, the most important transformations in starch material, caused by extrusion and dependent on the water content, are gelatinization, dextrinisation, and melting. Transformations have an enormous effect on the physical properties of the endproduct (WLODARCZYK-STASIAK; JAMROZ, 2008; PÉREZNAVARRETE et al., 2008).

For the production of nutritious acceptable snacks, rates of starch fortification seem to vary according to the nature of each material (BERRIOS et al., 2004). Desirable properties in the extrudates are obtained by finding the appropriate processing condition as well as the proper composition of the raw material. Therefore, the aim of this study was to investigate the effect of extrusion temperature, screw speed, moisture content, and amount of quinoa flour on the physical properties of puffed snacks.

\section{Materials and methods}

The raw materials used were industrial sour cassava starch (Ouro Minas industry- São Pedro do Turvo, São Paulo, Brazil) and quinoa flour (Jasmine, Brazil). Cassava starch and quinoa flour blends were prepared containing $5,10,15$, and $20 \%$ of quinoa flour (wet basis). After homogenization in a homogenizer in "Y" TE201/5 (Tecnal, Brazil) for 5 minutes, 28 samples of $1 \mathrm{~kg}$ were separated for moisture conditioning.

Extrusion was carried out using a complete line of INBRA RX 50 (Inbramaq, Brazil), which has a motor coupled with a speed reducer (extrusion by mechanical friction), and a single extrusion screw with $130 \mathrm{~mm}$ barrel diameter and $440 \mathrm{~mm}$ extruder length, a hydraulic cooling system for temperature control, variable speed, and $50 \mathrm{~kg} \cdot \mathrm{h}^{-1}$ capacity.

The extrusion process parameters were:

- Constant parameters: extrusion temperature in the $1^{\text {st }}(20$ to $25^{\circ} \mathrm{C}$ ) and $2^{\text {nd }}$ zones $\left(40\right.$ to $45^{\circ} \mathrm{C}$ ); screw compression ratio (3:1); screw diameter $(32,6 \mathrm{~mm})$, die diameter $(4 \mathrm{~mm})$; feed rate $\left(150\right.$ g.minutes $\left.{ }^{-1}\right)$; and cutting speed (90 rpm).

- Variable parameters: quinoa flour amount, feed moisture; barrel temperature in the $3^{\text {rd }}$ zone; and screw speed (Table 1). The variation ranges between the upper and the lower limit of variables were established based on preliminary tests.

During the extrusion process, a portion of the next test material was used to purge the extruder. A total of $500 \mathrm{~g}$ of extruded sample were collected after achieving steady-state flow in the extruder. The extruded samples were dried $\left(40^{\circ} \mathrm{C}\right)$

Table 1. Levels of variation and variable parameters of the extrusion process.

\begin{tabular}{|c|c|c|c|c|c|}
\hline \multirow{2}{*}{$\begin{array}{l}\text { Independent } \\
\text { variables }\end{array}$} & \multicolumn{5}{|c|}{ Levels of variation } \\
\hline & $-<$ alpha $>$ & -1 & 0 & +1 & $+<$ alpha $>$ \\
\hline Quinoa flour & 0 & 5 & 10 & 15 & 20 \\
\hline Screw speed (rpm) & 230 & 240 & 250 & 260 & 270 \\
\hline Extrusion temperature $\left({ }^{\circ} \mathrm{C}\right)$ & 80 & 90 & 100 & 110 & 120 \\
\hline Moisture content (\%) & 14 & 16 & 18 & 20 & 22 \\
\hline
\end{tabular}

$<$ alpha $>=2.0$. 
to the desired moisture (6-7\%) in an oven with air circulation (Marconi - MA037 Brazil). Each dried samples was divided in two portions and kept in plastics bags hermetically sealed until evaluation. A portion of each sample was powdered using a knife mill (Marconi-MA 680, Brazil) with screen of $468 \mathrm{~mm}$.

The expansion index (EI) was evaluated after extrusion and before drying. It was determined using a digital caliper. Expansion indexes are derived from the division of radial expansion by the die orifice diameter $(4.0 \mathrm{~mm})$. The considered value was obtained by the arithmetic mean of measurements of 20 different expanded products in each treatment (FAUBION; HOSENEY, 1982).

Specific volume (SV) was determined according to the mass displacement method (millet seed) using a graded pipette (FAUBION; HOSENEY, 1982).

Water absorption index (WAI) and water solubility index (WSI) were assessed before and after extrusion process (ANDERSON et al., 1969). The water absorption index (WAI) is the weight of gel obtained per gram of dry ground sample. The extrudates were ground to a mean particle size of approximately $150 \mu \mathrm{m}$. A $2.5 \mathrm{~g}$ sample was dispersed in $25 \mathrm{~g}$ of distilled water using a glass rod to break up any lumps. After stirring for 30 minutes, the dispersions were rinsed into tarred centrifuge tubes, made up to $32.5 \mathrm{~g}$, and centrifuged at $5000 \mathrm{rpm}$ for 10 minutes. The water absorption index (WAI) is the weight of gel obtained per gram of dry ground sample. The water solubility index (WSI) is the percentage of dry matter recovered after the supernatant is evaporated from the water absorption determination.

Color measurements (CIE L*, $\mathrm{a}^{*}, \mathrm{~b}^{*}$ color space) were performed on ground samples using a Minolta CR-400 model colorimeter (Konica Minolta, Ramsey, NJ, USA). The color of extrudates was expressed as the average of three $L^{*}, a^{*}$, and $b^{*}$ readings, where $L^{\star}$ stands for brightness, $+a^{*}$ redness, $-a^{*}$ greenness, $+\mathrm{b}^{\star}$ yellowness, and $-\mathrm{b}^{\star}$ blueness. A white calibration plate was used to standardize the equipment prior to color measurements.

The hardness of samples was determined using a texture analyzer TA-XT2 (Stable Micro Systems, Surrey, England) with a $50 \mathrm{~kg}$ load cell and a probe HDP/WBV (Warner Bratzler set with "V" slot blade for USDA Standart). The test speed was $1 \mathrm{~mm} / \mathrm{s}$. Ten extrudates were assayed for each treatment.

Response Surface Methodology describes the behavior of a system in which the independent variables $\left(\mathrm{X}_{\mathrm{k}}\right)$ and the dependent variable or response $\left(\mathrm{Y}_{\mathrm{i}}\right)$ are combined. The response is a function of the levels at which those factors were combined and defined.

Within the proposed variation ranges, i.e. within the region characterized by these levels, the behavior of each response can be predicted in a general form according to the Equation 1:

$$
\begin{aligned}
& Y_{1}=\beta_{0}+\beta_{1} X_{1}+\beta_{2} X_{2}+\beta_{3} X_{3}+\beta_{4} X_{4}+\beta_{11} X_{1}^{2}+\beta_{22} X_{2}^{2}+ \\
& +\beta_{33} X_{3}^{2}+\beta_{44} X_{4}^{2}+\beta_{12} X_{1} X_{2}+\beta_{13} X_{1} X_{3}+\beta_{14} X_{1} X_{4}+ \\
& +\beta_{23} X_{2} X_{3}+\beta_{24} X_{2} X_{4}+\beta_{34} X_{3} X_{4}+\varepsilon
\end{aligned}
$$

where: $Y_{1}=$ Dependent variable or response function; $X_{1}, X_{2}$, $\mathrm{X}_{3}, \mathrm{X}_{4}=$ Values of the independent variables; $\beta_{\mathrm{o}}=$ Coefficient relative to the line interception with the response axis; $\beta_{1}, \beta_{2}, \beta_{3}$, $\beta_{4}=$ Linear coefficients assessed through least square method; $\beta_{11}, \beta_{22}, \beta_{33}, \beta_{44}=$ Coefficients of quadratic variables; $\beta_{12}, \beta_{13}, \beta_{14}$, $\beta_{23}, \beta_{24}, \beta_{34}=$ Coefficients of interaction between independent variables; $\varepsilon=$ Experimental error.

The model was fitted by the option "step-wise" of SAS program; the obtained model was validated through F-test using the pure error mean square as denominator.

The response surfaces plots were drawn from the adjusted models using the software Statistica ${ }^{\circledast} 6.0$.

\section{Results and discussion}

The color analysis of blends before extrusion showed the high brightness of the sour cassava starch (94.68), $\mathrm{a}^{\star}$ positive (1.1) and $b^{\star}$ positive (5.96). The quinoa flour showed lowest brightness (89.6), lower presence of $+a^{*}(0.09)$ and greater presence of yellow $\left(12.66 \mathrm{of}+\mathrm{b}^{\star}\right)$.

Sour cassava starch showed low water solubility index $(2.11 \%)$ and water absorption index $\left(0.82 \mathrm{~g}\right.$ gel.g $\left.{ }^{-1}\right)$ before extrusion. The quinoa flour had higher WSI (8.97\%) and WAI $\left(2.9\right.$ g gel. $\left.^{-1}\right)$.

Low water absorption index and water solubility index in cassava starch before extrusion process were also found in other studies (LEONEL; FREITAS; MISCHAN, 2009; LEONEL; MARTINS; MISCHAN, 2010). The water absorption index found for quinoa flour was higher than that reported for unprocessed quinoa flour (1.69 g gel.g $^{-1}$ ) (DOGAN; KARWE, 2003).

Table 2 summarizes the estimated regression coefficients for the models fitted to the experimental results and their significance as well as their corresponding coefficients of determination.

The degree of expansion of an extruded product is closely related to the size, number and distribution of air cells surrounded by the cooked material. High pressure close to the discharge of the matrix is reduced when the products leaves the extruder causing flash evaporation of water and expansion of the product.

The expansion index ranged from 2.58 to 4.65. Data analysis showed negative linear effect of moisture and the effect of the interaction of the amount of quinoa flour and moisture on the expansion index of the products (Table 2). According to the adjusted model higher expansion index are obtained under conditions of lower moisture (Figure 1a).

Specific volume is a major performance index for extrusion puffed food. It is a measure of volumetric expansion, which is the sum of radial and axial expansions. The specific volume of extruded products ranged from $4.11 \mathrm{~mL} \cdot \mathrm{g}^{-1}$ to $10.76 \mathrm{~mL} . \mathrm{g}^{-1}$, with values close to the average specific volume of commercial corn snacks $\left(8.72 \mathrm{~mL} . \mathrm{g}^{-1}\right)$. 
The analysis of the regression coefficients showed linear effects of the amount of quinoa flour and moisture on the specific volume of products (Table 2). Under conditions of low moisture and higher amount of quinoa flour, temperature at $100{ }^{\circ} \mathrm{C}$, and $250 \mathrm{rpm}$ of screw speed, the largest specific volumes are observed (Figure $1 \mathrm{~b}$ ).

Similar result was observed in a study on the effects of adding soy protein isolate $(0-50 \%)$, initial moisture content $(17.96$ to $28.04 \%$ ), and process temperature (from 106.4 to $173.6^{\circ} \mathrm{C}$ ) in the development of expanded snack based on cassava starch, and it was concluded that expansion increased with higher temperatures and high content of protein (CHANG et al., 2001).
When starch is extrusion-cooked, expansion is dependent on the formation of a starch matrix that entraps the water vapor resulting in the formation of bubbles. The expansion of starchy materials is inversely proportional to the moisture of raw material. Increased moisture can change the molecular structure of amylopectin reducing the elastic viscosity and thus decreasing the expansion (DING et al., 2005; GUY; HORNE, 1988). In tested conditions of lower moisture, the expansion index and specific volume of the snacks were higher. Low moisture content in the mixtures may have restrained its flow inside the extruder increasing shear and residence time, thus increasing the gelatinization degree and the expansion.

Table 2. Regression equation coefficients (model $Y_{1}=\beta_{0}+\beta_{1} X_{1}+\beta_{2} X_{2}+\beta_{3} X_{3}+\beta_{4} X_{4}+\beta_{11} X_{1}^{2}+\beta_{22} X_{2}^{2}+\beta_{33} X_{3}^{2}+\beta_{44} X_{4}^{2}+\beta_{12} X_{1} X_{2}+\beta_{13} X_{1} X_{3}+\beta_{14} X_{1} X_{4}+\beta_{23} X_{2} X_{3}+$ $\left.\beta_{24} \mathrm{X}_{2} \mathrm{X}_{4}+\beta_{34} \mathrm{X}_{3} \mathrm{X}_{4}+\varepsilon\right)$

\begin{tabular}{|c|c|c|c|c|c|c|c|c|}
\hline \multirow{2}{*}{ Parameters } & \multicolumn{8}{|c|}{ Response variables } \\
\hline & EI & SV & WAI & WSI & $L^{*}$ & $a^{*}$ & $\mathrm{~b}^{*}$ & $\mathrm{H}$ \\
\hline$\beta_{0}$ & 3.497 & 8.437 & 7.127 & 9.873 & 63.91 & 6.137 & 18.003 & 1.310 \\
\hline$\beta_{1}$ & -0.063 & $0.693^{*}$ & -0.011 & -0.867 & 1.088 & -0.015 & $1.158^{\star *}$ & 0.116 \\
\hline$\beta_{2}$ & -0.027 & -0.027 & -0.258 & $-1.802^{\star *}$ & -0.436 & 0.005 & 0.139 & 0.078 \\
\hline$\beta_{3}$ & 0.005 & 0.006 & $0.875^{\star * *}$ & $6.213^{* * *}$ & 0.784 & 0.022 & 0.565 & -0.177 \\
\hline$\beta_{4}$ & $-0.378^{\star * *}$ & $-1.228^{\star * *}$ & $-0.909^{\star * *}$ & $-8.151^{\star * *}$ & -0.295 & -0.064 & -0.333 & -0.156 \\
\hline$\beta_{11}$ & 0.066 & 0.241 & $0.572^{\star *}$ & $1.664^{\star *}$ & $2.269^{\star *}$ & $-0.251^{\star \star}$ & 0.009 & $1.274^{\star \star * *}$ \\
\hline$\beta_{22}$ & 0.007 & $-0.495^{\star}$ & 0.310 & $1.132^{*}$ & $1.428^{\star}$ & -0.006 & 0.286 & 0.167 \\
\hline$\beta_{33}$ & -0.004 & $-0.523^{*}$ & $0.982^{* * *}$ & $4.349^{* * *}$ & $1.876^{\star *}$ & $-0.234^{*}$ & -0.133 & -0.083 \\
\hline$\beta_{44}$ & -0.037 & -0.344 & $0.566^{\star *}$ & $2.747^{\star \star *}$ & 0.826 & -0.121 & 0.071 & -0.093 \\
\hline$\beta_{12}$ & -0.042 & -0.307 & -0.281 & $-1.828^{\star *}$ & 0.540 & -0.048 & -0.416 & 0.261 \\
\hline$\beta_{13}$ & 0.113 & -0.375 & 0.219 & 1.269 & 0.442 & -0.167 & -0.524 & 0.095 \\
\hline$\beta_{14}$ & $0.158^{\star}$ & 0.281 & $0.549^{\star}$ & 0.303 & -0.121 & -0.013 & 0.486 & 0.260 \\
\hline$\beta_{23}$ & 0.022 & 0.306 & 0.018 & 0.667 & 0.915 & -0.033 & -0.274 & 0.281 \\
\hline$\beta_{24}$ & 0.057 & -0.382 & $0.613^{* *}$ & $2.125^{\star *}$ & 0.914 & -0.059 & 0.436 & 0.254 \\
\hline$\beta_{34}$ & -0.066 & -0.140 & -0.237 & $-3.371^{\star \star}$ & -1.161 & $0.257^{\star}$ & 0.702 & -0.302 \\
\hline $\mathrm{R}^{2}$ & 0.841 & 0.736 & 0.887 & 0.969 & 0.706 & 0.633 & 0.694 & 0.802 \\
\hline
\end{tabular}

$\beta_{1}=$ percentage of quinoa flour, $\beta_{2}=$ screw speed, $\beta_{3}=$ extrusion temperature, $\beta_{4}=$ moisture, $\mathrm{EI}=$ expansion index, $\mathrm{SV}=$ specific volume, WAI= water absorption index, WSI= water solubility index, $\mathrm{L}^{*}=$ luminosity, $\mathrm{a}^{*}=$ chroma $\mathrm{a}^{*}, \mathrm{~b}^{*}=$ chroma $^{*}, \mathrm{H}=$ hardness. $\left({ }^{*}=\mathrm{p}<0.05 ;{ }^{* *}=\mathrm{p}<0.01 ;{ }^{* *}=\mathrm{p}<0.001\right)$.
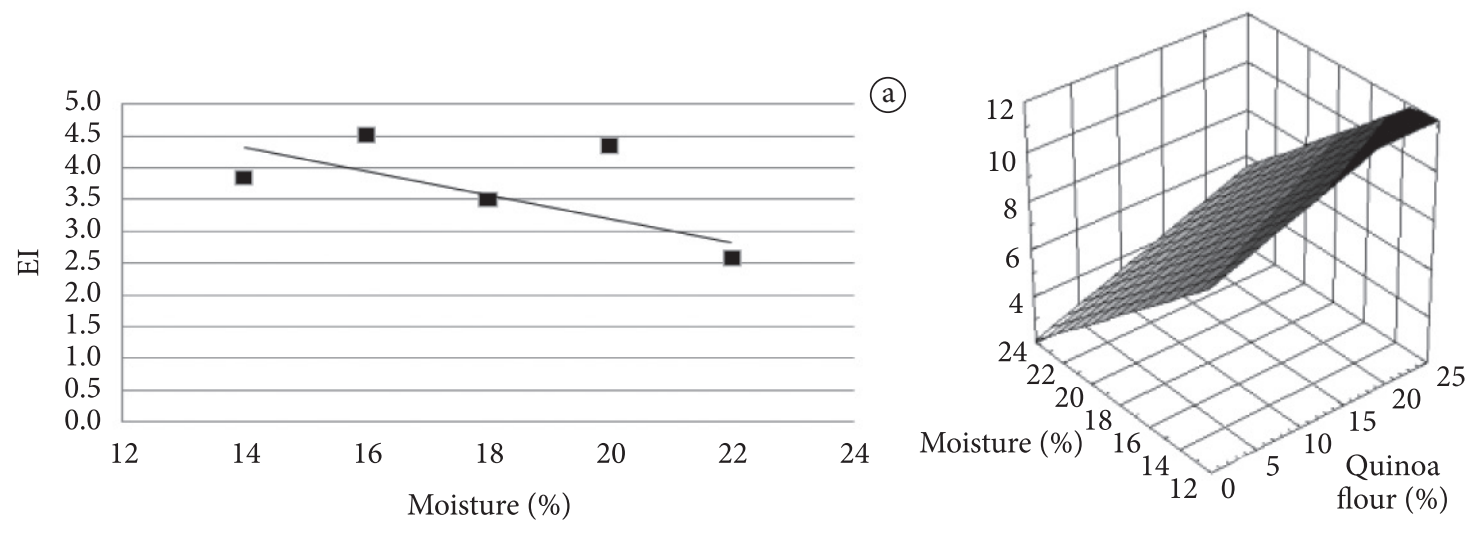

Figure 1. Effects of moisture (\%) on expansion index (a) and effect of the interaction of quinoa flour and moisture on the specific volume (b) of extruded products. 
Water solubility index (WSI), often used as an indicator of degradation of molecular components, measures the degree of starch conversion during extrusion, which is the amount of soluble polysaccharide released from the starch component after extrusion (YANG et al., 2008). The values obtained for the water solubility index of the extruded products ranged from $4.95 \%$ to $42.37 \%$. Considering the WSI of blends before extrusion (2.15 to $2.24 \%$ ), there was a pronounced increase in solubility with the process, independent of the tested conditions.

The analysis of the regression coefficients showed significant effects of all process parameters on the WSI (Table 2). Higher levels of water solubility are observed in conditions of high amount of quinoa flour in the mixture and low screw speed, as well as, under conditions of high temperature and high amount of quinoa flour (Figure 2).

The water solubility index of the extruded products is higher under the conditions of low moisture and low screw speed (Figure 2).

The increase in water solubility index with increasing temperature and decreasing moisture was consistent with results reported for quinoa flour extrudes (DOGAN; KARWE, 2003).
According to the response surface plot drawn from the adjusted model, under the conditions of high moisture and low extrusion temperature, high levels of solubility in water are observed (Figure 2).

The extruded products showed improvement in solubility and water absorption. The knowledge of interactions between proteins with starch is still scarce. There are not many studies concerning the changes in structure of components and the chemical reactions during extrusion cooking (WLODARCZYKSTASIAK; JAMROZ, 2008). The WSI depends on the intensity and type of reactions that occur during extrusion, influencing the amount of soluble molecules. In addition to starch gelatinization, which results in the release of amylose and amylopectin, dextrinisation process and other reactions that lead to the formation of low molecular weight compounds, influencing the WSI can also occur (CAMIRE; CAMIRE; KRUMHAR, 1990).

An increase in the amount of dextrinized starch during extrusion cooking results in an increase in water solubility index. However, molecular interactions between degraded starch, protein, and lipid components may reduce solubility (DOGAN; KARWE, 2003).
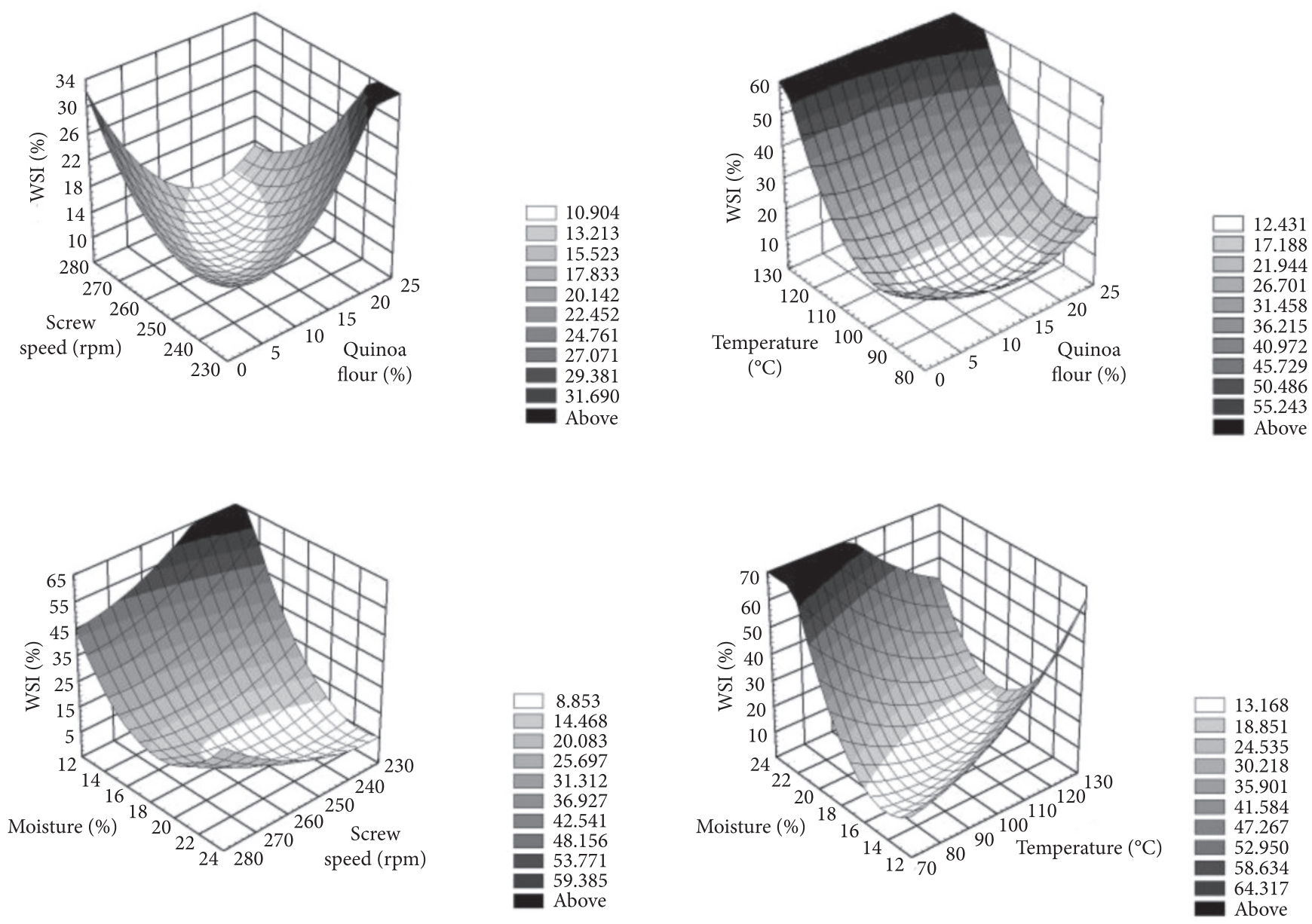

Figure 2. Effects of extrusion parameters on water solubility index of extruded products. 
The high friction promoted by low moisture combined with longer exposure to center point temperature $\left(100^{\circ} \mathrm{C}\right)$, due to slow rotation of the screw, may have contributed to the collapse of the crystalline structure of starch granules and protein denaturation of quinoa flour leading to an increase in solubility.

The water absorption index (WAI) measures the volume occupied by the starch after swelling in excess water and indicates the integrity of starch in aqueous dispersion. The water absorption index of extrudates ranged from 7.06 to 13.37 g gel. $\mathrm{g}^{-1}$.

Statistical analysis of experimental results showed linear effects of temperature and moisture, positive quadratic effects of quinoa flour amount, temperature, and moisture, as well as, effects of the interactions between the quinoa flour amount and moisture, and moisture and screw speed on the water absorption index of extruded products (Table 2). Higher water absorption index is observed under high temperature and low moisture conditions (Figure 3). Under conditions of low moisture and lower amount of quinoa flour, the absorption in water had higher value (Figure 3). On the other hand, under the intermediate conditions of temperature and moisture, the WAI was lower (Figure 3).

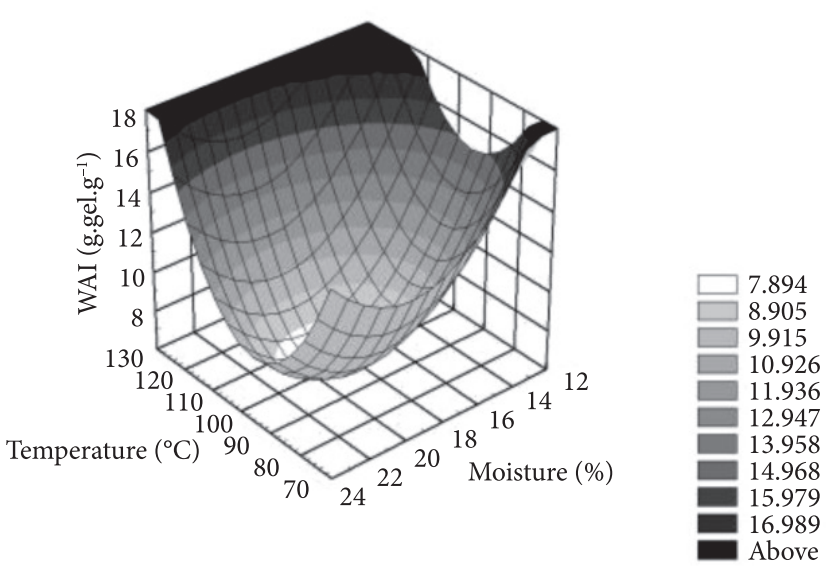

An increase in the value of WAI may probably be caused by uncovering of hydrophilic groups in extruded starch-protein material, by unfolding and loosening of biopolymer chains, greater availability, and easier penetration of structures by water molecules (MARZEC; LEWICKI, 2006).

Color is an important characteristic of extruded foods. Color changes can give information about the extent of browning reactions such as caramelization, Maillard reaction, degree of cooking, and pigment degradation that take place during the extrusion process (ANTON et al., 2008).

Analysis of the color components of the blends before and after extrusion evidenced that the values of the $\mathrm{L}^{*}$ component from extruded products varied from 53.05 to 74.69 indicating a decrease in luminosity after extrusion when compared with the initial luminosity of blends (93.56). The analysis of the regression coefficients showed positive quadratic effects of the amount of quinoa flour, screw speed, and extrusion temperature on the luminosity of the extruded products (Table 2). Lower luminosity (darker products) is obtained under intermediate conditions of variable parameters of the process (Figure 4).

Chroma a ${ }^{*}$ values ranged from 4.64 to 6.43 , which indicates that there was little variability in this parameter during the extrusion process, considering that it can vary from -60 to

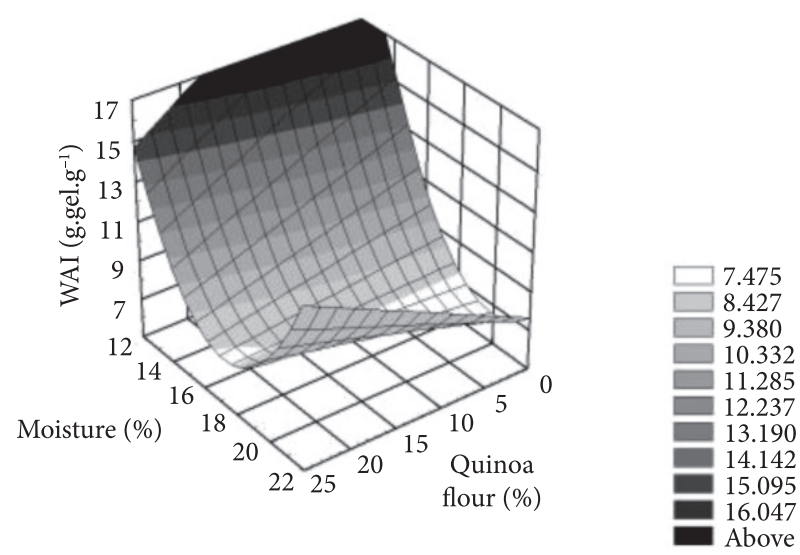

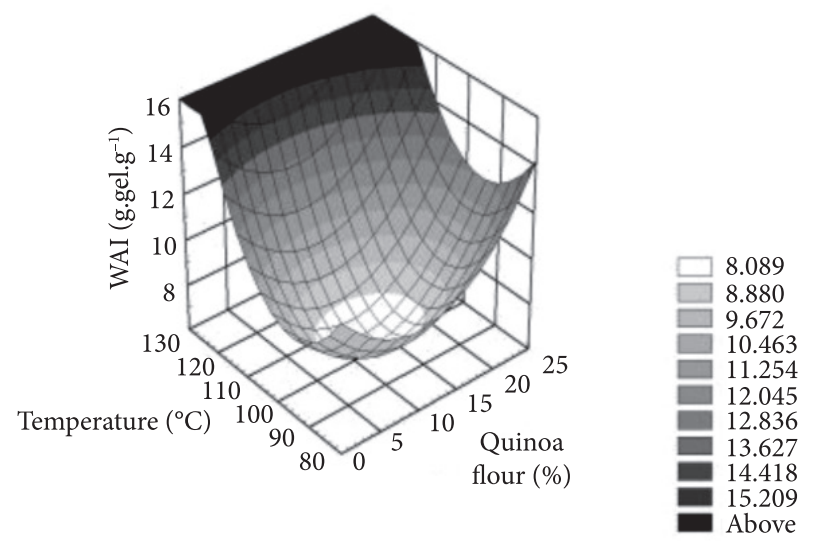

Figure 3. Effects of extrusion parameters on water absorption index of extruded products. 
+60. The extrusion process intensified the color red, given that blends showed chroma ${ }^{*}$ of 0.81 . Data analysis showed negative quadratic effects of the amount of quinoa flour and temperature on this component of chromaticity (Table 2).

According to the model, under the extreme conditions of temperature and amount of quinoa flour, with moisture and screw speed at the central point, low $\mathrm{a}^{*}$ is observed with higher values at the central point of all variable parameters of the extrusion process (Figure 5a)

Responses of the $\mathrm{b}^{*}$ color parameter, which represents variation from blue to yellow, varied according to the treatment (from 10.88 to 20.86). After the extrusion process, it can be
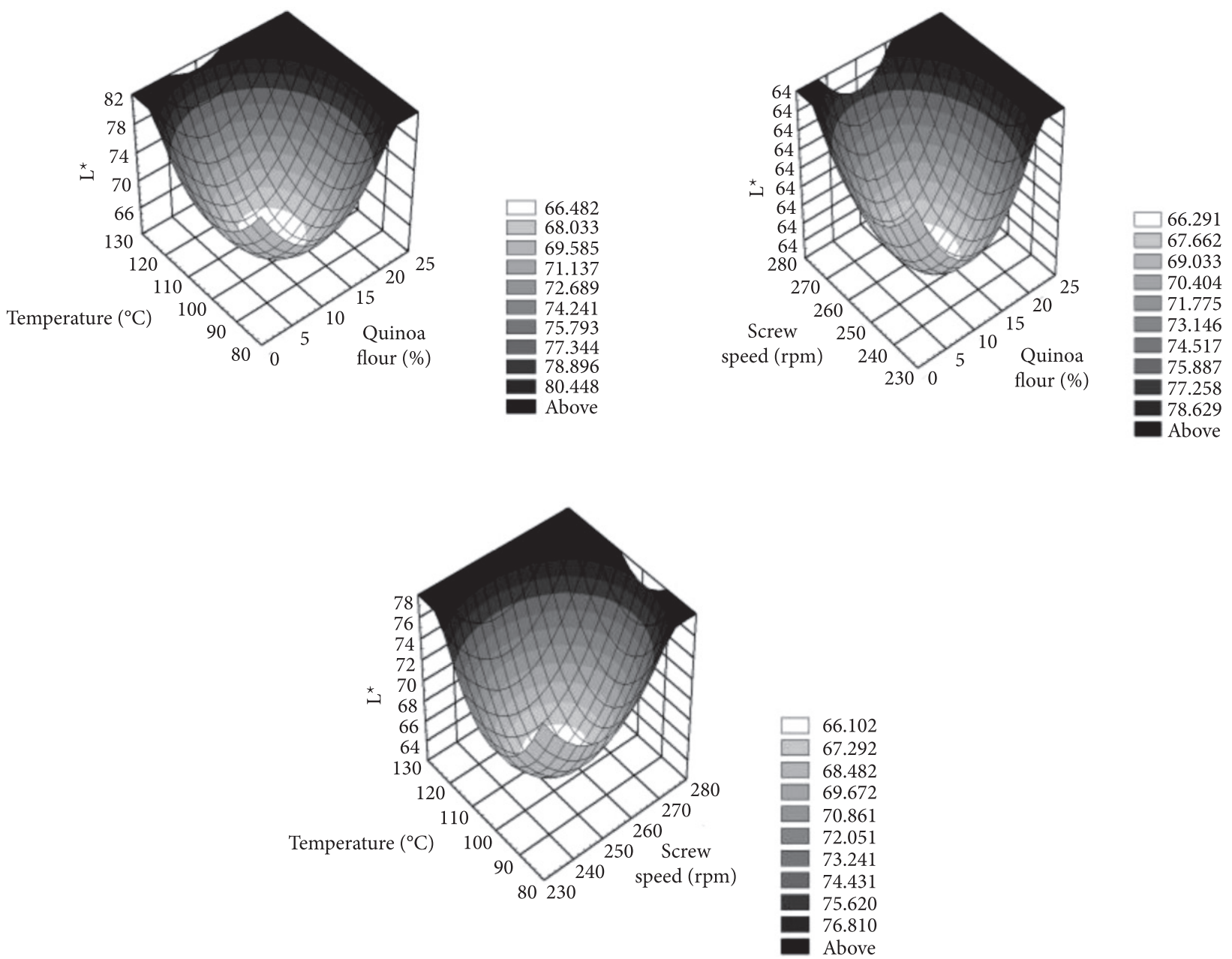

Figure 4. Effects of extrusion parameters on the luminosity values of extruded products.

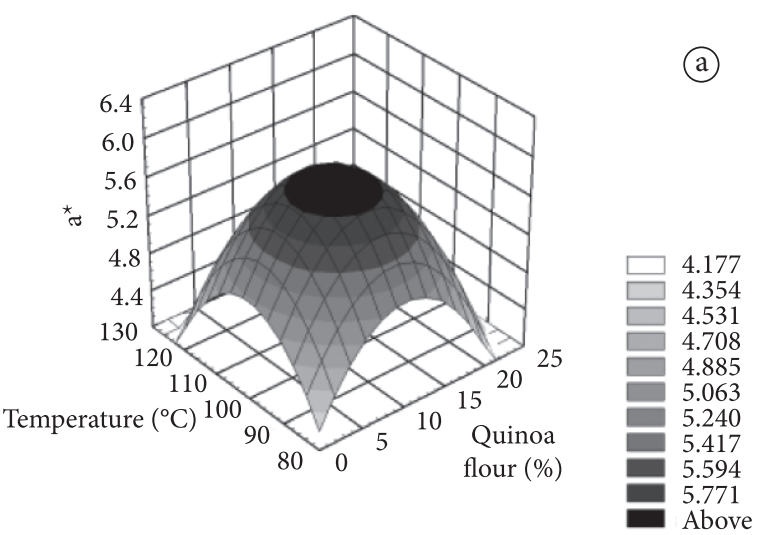

(b)

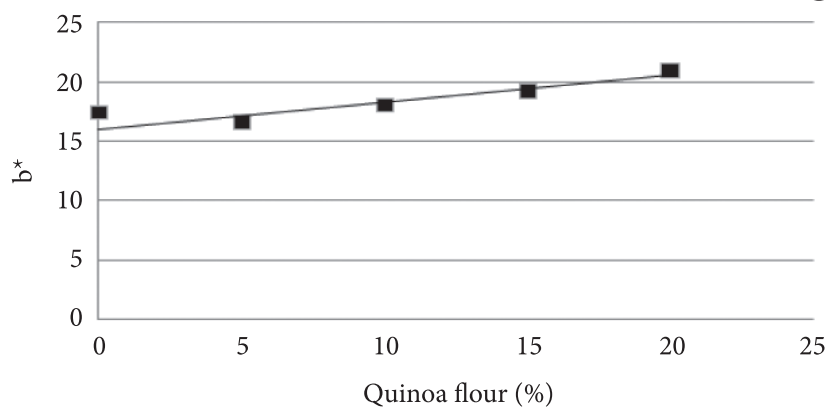

Figure 5. Effects of extrusion parameters on chroma $\mathrm{a}^{\star}(\mathrm{a})$ and chroma $\mathrm{b}^{\star}(\mathrm{b})$ of extruded products. 


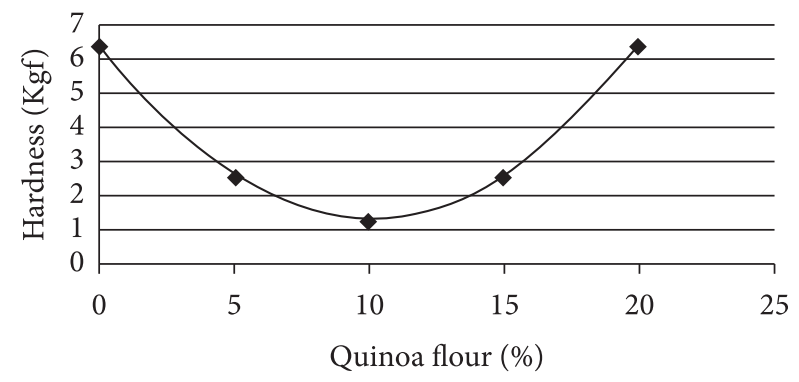

Figure 6. Effect of quinoa flour amount on the hardness extruded products.

observed that yellow was intensified since the blends showed chroma $b^{*}$ of 7.56 .

Regression analysis indicated linear effects of quinoa flour amount on this chromaticity component (Table 2). The increase in the amount of quinoa flour increases color intensity (Figure 5b).

The textural property of the samples was determined by measuring the force required to break the extrudate. The hardness of the extruded products ranged from 0.87 to $2.03 \mathrm{kgf}$ (8.53 to $19.91 \mathrm{~N}$ ), minimum and maximum values, respectively. From the data obtained for the different tests, it was observed the positive quadratic effect of quinoa flour on hardness (Figure 6).

It is reasonable to suggest that the addition of quinoa flour (high content of protein and lipids) might have affected the character of the starch matrix (i.e., the viscoelastic properties of molten extrudate) so that it no longer holds water vapor, resulting in higher break strength.

The higher the value of maximum peak force required in gram, which means the more force required to breakdown the sample, the higher the hardness of the sample to fracture (LI et al., 2005).

\section{Conclusion}

The operational conditions of the extrusion process affect physical properties of sour cassava starch and quinoa flour snacks. Snacks with good technological characteristics can be obtained under the conditions of $10 \%$ of quinoa flour, $250 \mathrm{rpm}$ of screw speed, temperature of $100{ }^{\circ} \mathrm{C}$, and moisture of $15 \%$. Extrusion is an attractive process to obtain sour cassava starch snacks with different nutrients.

\section{Acknowledgements}

The authors acknowledge the financial support of CNPq and FAPESP, Brazil.

\section{References}

ANDERSON, R. A. et al. Gelatinization of corn grits by roll and extrusion cooking. Cereal Science Today, v. 14, n. 1, p. 4-11, 1969.

ANTON, A. A. et al. Influence of added bean flour (Phaseolus vulgaris L.) on some physical and nutritional properties of wheat flour tortillas. Food Chemistry, v. 109, n. 1, p. 33-41, 2008. http:// dx.doi.org/10.1016/j.foodchem.2007.12.005

BERTOLINI, A. C. et al. Relationship between thermomechanical properties and baking expansion of sour cassava starch (Polvilho azedo). Journal of the Science of Food and Agriculture, v. 81, n. 4 , p. $429-435,2001$. http://dx.doi.org/10.1002/10970010(200103)81:4<429::AID-JSFA833>3.0.CO;2-2

BERRIOS, J. J. et al. Sodium bicarbonate and the microstructure, expansion and color of extruded black beans. Journal of Food Processing and Preservation, v. 28, n. 5, p. 321-335, 2004. http:// dx.doi.org/10.1111/j.1745-4549.2004.24008.x

BHATNAGAR, S.; HANA, M. A. Amylose-lipid complex formation during single-screw extrusion of various corn starches. Cereal Chemistry, v. 71, n. 6, p. 582-587, 1994. Disponível em: $<$ http://199.86.26.57/cerealchemistry/backissues/1994/71_582. $\mathrm{pdf}>$.

BORGES, J. T. et al. Características físico-químicas, nutricionais e formas de consumo da quinoa (Chenopodium quinoa Willd.). Temas agrários, v. 15, n. 1, p. 9-23, 2010. Disponível em: <http:// www.unicordoba.edu.co/revistas/rta/documentos/15-1/RTA\%20 ON\%20LINE/ARTICULOS\%20RTA\%2015\%20(1)\%20PDF/1. CARACTERISTICAS\%20QUINOA.pdf $>$.

BRADY, K. et al. Effects of processing on the nutraceutical profile of quinoa. Food Chemistry, v. 100, n. 3, p. 1209-1216, 2007. http:// dx.doi.org/10.1016/j.foodchem.2005.12.001

CAMIRE, M. E.; CAMIRE, A.; KRUMHAR, K. Chemical and nutritional changes in foods during extrusion. Critical Reviews in Food Science and Nutrition, v. 29, n. 1, p. 35-57, 1990. http:// dx.doi.org/10.1080/10408399009527513

CHANG, Y. K. et al. Influence of extrusion condition on cassava starch and soybean protein concentrate blends. Acta Alimentaria, v. 30, n. 2, p. 189-203, 2001. Disponível em: <http://cat.inist.fr/?aModel $\mathrm{e}=$ afficheN\&cpsidt $=14061837>$.

DE PILLI, T. et al. Study of starch-lipid complexes in model system and real food produced using extrusing-cooking technology. Innovative Food Science and Emerging Technologies, v. 12, n. 4, p. 610-616, 2011. http://dx.doi.org/10.1016/j.ifset.2011.07.011

DING, Q. et al. The effect of extrusion conditions on the physicochemical properties and sensory characteristics of rice-based expanded snacks. Journal of Food Engineering, v. 66, n. 3, p. 283-289, 2005. http://dx.doi.org/10.1016/j.jfoodeng.2004.03.019

DOGAN, H.; KARWE, M. V. Physicochemical properties of quinoa extrudates. Food Science and Technology International, v. 9, n. 2, p. 101-114, 2003. http://dx.doi.org/10.1177/1082013203009002006

FAUBION, J. M.; HOSENEY, R. C. High temperature and short time; extrusion-cooking of wheat starch and flour. I. Effect of moisture and flour type on extrudate properties. Cereal Chemistry, v. 59, n. 6, p. 529-533, 1982. Disponível em: <http://www.aaccnet.org/ cerealchemistry/backissues/1982/chem59_529.pdf >.

GUY, R. Extrusion cooking: Technologies and applications. Cambridge: Woodhead Publishing, 2001.288 p.

GUY, R. C. E.; HORNE, A. Extrusion and co-extrusion of cereals. In: BLANSHARD, J. M. V.; MITCHELL, J. R. (Eds.). Food Structure-Its Creation and Evaluation. London: Butterworths, 1988. p. 331-349.

HARPER, J. M. Extrusion of foods. Boca Raton: CRC Press, 1981.212 p.

JAMES, L. E. A. Quinoa (Chenopodium quinoa Willd): composition, chemistry, nutritional and functional properties. Advances in Food and Nutrition Research, v. 58, n. 1, p. 1-31, 2009. PMid:19878856.

LEONEL, M.; FREITAS, T. S.; MISCHAN, M. M. Physical characteristics of extruded cassava starch. Scientia Agricola, 
v. 66, n. 4 , p. $486-493$, 2009. http://dx.doi.org/10.1590/S010390162009000400009

LEONEL, M.; MARTINS, J. C.; MISCHAN, M. M. Produção de snacks funcionais à base de farinha de soja e polvilho azedo. Ciência Rural, v. 40, n. 6, p. 1418-1423, 2010. http://dx.doi.org/10.1590/ S0103-84782010000600027

LI, S. et al. Textural modification of soya bean/corn extrudates as affected by moisture content, screw speed and soya bean concentration. International Journal of Food Science and Technology, v. 40, n. 8, p. 731-741, 2005. http://dx.doi.org/10.1111/ j.1365-2621.2005.00993.x

MARZEC, A.; LEWICKI, P. P. Antiplasticization of cereal-based products by water. Part I: extruded flat bread. Journal of Food Engineering, v. 73, n. 1, p. 1-8, 2006. http://dx.doi.org/10.1016/j. jfoodeng.2004.12.002
OGUNGBENLE, H. Nutritional evaluation and functional properties of quinoa (Chenopodium quinoa) flour. International Journal of Food Science and Nutrition, v. 54, n. 2, p. 153-158, 2003. PMid:12701372.

PÉREZ-NAVARRETE, C. et al. Effect of extrusion on nutritional quality of maize and lima bean flour blends. Journal of the Science of Food and Agriculture, v. 86, n. 14, p. 2477-2484, 2008. http:// dx.doi.org/10.1002/jsfa.2661

WLODARCZYK-STASIAK, M.; JAMROZ, J. Analysis of sorption properties of starch-protein extrudates with the use of water vapour. Journal of Food Engineering, v. 85, n. 4, p. 580-589, 2008. http:// dx.doi.org/10.1016/j.jfoodeng.2007.08.019

YANG, S. H. et al. Effects of adlay species and rice flour ratio on the physicochemical properties and texture characteristic of adlay-based extrudates. Journal of Food Enginering, v. 84, n. 3, p. 489-494, 2008. http://dx.doi.org/10.1016/j.jfoodeng.2007.06.010 